\title{
PELAKSANAAN KONSEP DASAR KESELAMATAN DAN KESEHATAN \\ KERJA (K3) DI RUMAH SAKIT
}

\author{
Fanisa Nur Siregar \\ fanisanursiregar09@gmail.com
}

\section{LATAR BELAKANG}

Di era globalisasi ini keselamatan dan kesehatan kerja rumah sakit merupakan salah satu syarat yang telah ditetapkan dalam menjalankan fungsi dari rumah sakit. Keselamatan dan kesehatan kerja merupakan hal yang penting untuk dilaksanakan dalam lingkungan kerja terutama adalah rumah sakit. Keselamatan dan kesehatan kerja adalah kegiatan yang dirancang untuk menjamin keselamatan dan kesehatan pekerja di tempat kerja.

Kesehatan dan Keselamatan Kerja (K3) merupakan salah satu isu penting di dunia kerja saat ini termasuk di lingkungan rumah sakit. Angka kecelakaan kerja di rumah sakit lebih tinggi dibandingkan tempat kerja lainnya dan sebagian besar diakibatkan oleh perilaku yang tidak aman. Kecelakaan kerja menjadi salah satu masalah genting di lingkungan rumah sakit. Hal ini diakibatkan karena rumah sakit merupakan suatu unit pelayanan kesehatan yang memberikan pelayanan pada semua bidang dan jenis penyakit.

Oleh sebab itu rumah sakit dituntut untuk dapat menyediakan serta menerapkan sebuah upaya agar semua sumber daya manusia yang bekerja di rumah sakit dapat terlindungi, baik dari penyakit maupun kecelakaan akibat kerja. Pemerintah melakukan berbagai upaya untuk mengatasi kecelakaan kerja di rumah sakit, salah satunya adalah dengan dikeluarkannya UndangUndang Nomor 23 Tahun 1992 dan Undang-Undang Nomor 36 Tahun 2009 tentang penerapan Kesehatan dan Keselamatan Kerja di rumah sakit.

Di rumah sakit, perawat sangat berisiko terhadap kecelakaan dan penyakit akibat pekerjaan yang dilakukannya. Perawat adalah tenaga kesehatan yang paling besar jumlahnya dan paling lama melakukan kontak dengan pasien, sehingga sangat berisiko dengan pekerjaannya, namun banyak perawat tidak menyadari terhadap risiko yang mengancam dirinya, melupakan keselamatan dan kesehatan kerja (K3). Data WHO (2004): Dari 35 juta pekerja kesehatan bahwa 
3 juta terpajan patogen darah (2 juta terpajan virus HBV, 0.9 juta terpajan virus $\mathrm{HBC}$ dan 170.000 terpajan virus HIV/ AIDS).

Kesehatan dan Keselamatan Kerja (K3) merupakan suatu upaya perlindungan kepada tenaga kerja dan orang lain yang memasuki tempat kerja terhadap bahaya dari akibat kecelakaan kerja. Tujuan K3 adalah mencegah, megurangi, bahkan menihilkan resiko penyakit dan kecelakaan akibat kerja (KAK) serta meningkatkan derajat kesehatan para pekerja sehingga produktivitas kerja meningkat

\section{METODE}

Metode dalam pembuatan jurnal ini dilakukan dengan cara mengumpulkan data dari buku, jurnal, dan thesis dan e-book, kemudian melakukan analisis secara mendalam terkait topik yang dibahas, serta bersifat subjektif yaitu proses penulisan yang lebih fokus pada landasan teori. Dan melakukan analisis buku dan e-jurnal yang relevan dan berfokus pada Pelaksanaan Konsep Dasar Keselamatan Dan Kesehatan Kerja (K3) Di Rumah Sakit . Dengan menggunakan sumber dengan terbitan paling tua tahun 2012. Adapun referensi akan dicantumkan dalam penulisan ini dengan jelas terdapat pada daftar pustaka pada bagian akhir penulisan.

\section{HASIL}

Kesehatan dan Keselamatan Kerja (K3) merupakan suatu upaya perlindungan kepada tenaga kerja dan orang lain yang memasuki tempat kerja terhadap bahaya dari akibat kecelakaan kerja. Tujuan K3 adalah mencegah, megurangi, bahkan menihilkan resiko penyakit dan kecelakaan akibat kerja (KAK) serta meningkatkan derajat kesehatan para pekerja sehingga produktivitas kerja meningkat.

Tujuan Kesehatan dan Keselamatan Kerja menurut Mangkunegara (2002) adalah agar setiap pegawai mendapat jaminan kesehatan dan keselamatan kerja baik secara fisik, sosial dan psikologis. K3 termasuk sebagai salah satu standar pelayanan yang dinilai dalam akreditasi sebuah rumah sakit, disamping standar-standar pelayanan lainnya. Pekerja di rumah sakit mempunyai risiko yang lebih tinggi dibandingkan dengan pekerja di industri lain untuk terkena penyakit Akibat Kerja (PAK) dan kecelakaan akibat kerja(KAK), maka perlu dibuat standar 
perlindungan bagi pekerja yang ada di rumah sakit. Perawat berisiko terkena kecelakaan dan penyakit akibat pekerjaan dalam memberikan asuhan keperawatan.

Kecelakaan di tempat kerja memiliki dampak bagi individu maupun bagi institusi. Dampaknya bagi individu dapat berupa cedera ringan maupun berat, cacat, kematian. Dampak bagi institusi meliputi kerugian jiwa (cidera, cacat, kematian), kehilangan sumber daya berharga, biaya perawatan kesehatan, kerugian aset seperti uang, properti, gedung, peralatan, material, produk, serta mengurangi laba institusi karena menutup kerugian dari insiden. Menurut WHO yang dikutip oleh Swarjana (2017), faktor-faktor yang menyebab terjadinya kecelakaan kerja dan penyakit akibat kerja adalah:

a. Faktor manusia. Adapun faktor yang menyebabkan manusia dapat menimbulkan kecelakaan kerja atau penyakit akibat kerja diantaranya adalah umur, pengalaman kerja, penggunaan obat, dan motivasi.

b. Faktor lingkungan. Adapun penyebab kecelakaan kerja lainnya adalah faktor lingkungan pekerjaan. Seperti tingkat pencahyaan, tingkat kebisingan, temperature atupun suhu lingkungan, kesalahan konstruksi mesin, sikap badan yang tidak benar dalam melakukan pekerjaan, dan yang lain sebagainya.

c. Faktor organisasi. Kecelakaan kerja merupakan sebuah kejadian yang tidak diinginkan oleh siapa pun. Setiap pekerja pasti menginginkan untuk bekerja dengan nyaman, aman tanpa ada rasa cemas akan terjadinya kecelakaan di lingkungan kerja. Oleh karena itu, lingkungan sosial atau organisasi memiliki efek paling besar terhadap kinerja seseorang.

Pelaksanaan keselamatan dan kesehatan kerja di rumah sakit sudajh banyak di terapkan di berbagai rumah sakit di Indonesia. Karena K3 merupakan suatu syarat dalam suatu mutu rumah sakit.

\section{PEMBAHASAN}

Menurut Swarjana, keselamatan kerja adalah identifikasi risiko di tempat kerja dan pengukuran terhadap pencegahan yang diambil untuk menurunkan atau mengeliminasi hazards yang mungkin menyebabkan kecelakaan. Tujuan keselamatan kerja: 
- Mencegah kerusakan kesehatan dan mencegah terbuangnya sumber daya manusia dan sumber daya lainnya.

- Meningkatkan moral pekerja.

- Mencegah inefisiensi di tempat kerja yang disebabkan oleh efek dari kecelakaan.

- Mencegah bahaya sosial disebabkan oleh kecelakaan.

- Meningkatkan pencegahan terhadap kecelakaan

WHO dan ILO mendefinisikan kesehatan kerja pada tiga fokus yang berbeda, yaitu: Pemeliharaan dan promosi kesehatan karyawan dan kapasitas kerja, Peningkatan lingkungan kerja dan pekerjaan yang kondusif terhadap K3 karyawan, dan Pengembangan, pengorganisasian kerja dan budaya kerja ke arah yang mendukung kesehatan dan keselamatan di tempat kerja. Tujuan kesehatan kerja adalah

- Untuk memperoleh derajat kesehatan yang tinggi baik fisik, mental, dan sosial bagi masyarakat pekerja dan masyarakat di lingkungan perusahaan

- Pencegahan dan pemberantasan penyakit dan kecelakaan akibat kerja

- Pemeliharaan dan peningkatan kesehatan dan gizi tenaga kerja

- Perawatan untuk mempertinggi efisiensi dan produktivitas tenaga kerja

- Mengurangi kelelahan kerja

- Perlindungan bagi masyarakat sekitar suatu perusahaan agar terhindar dari bahayabahaya pencemaran yang ditimbulkan oleh perusahaan tersebut

\section{Pengertian K3RS}

Menurut International Labour Organization (ILO) kesehatan keselamatan kerja atau Occupational Safety and Health adalah meningkatan dan memelihara derajat tertinggi semua pekerja baik secara fisik, mental, dan kesejahteraan sosial di semua jenis pekerjaan, mencegah terjadinya gangguan kesehatan yang diakibatkan oleh pekerjaan, melindungi pekerja pada setiap pekerjaan dari risiko yang timbul dari faktor-faktor yang dapat mengganggu kesehatan, menempatkan dan memelihara pekerja di lingkungan kerja yang sesuai dengan kondisi fisologis dan psikologis pekerja dan untuk menciptakan kesesuaian antara pekerjaan dengan pekerja dan setiap orang dengan tugasnya. 
Pengertian K3 menurut OSHA adalah kesehatan dan keselamatan kerja adalah aplikasi ilmu dalam mempelajari risiko keselamatan manusia dan properti baik dalam industri maupun bukan. Kesehatan keselamatan kerja merupakan mulitidispilin ilmu yang terdiri atas fisika, kimia, biologi dan ilmu perilaku dengan aplikasi pada manufaktur, transportasi, penanganan material bahaya.

Keselamatan dan Kesehatan Kerja Rumah Sakit (K3RS), Berdasarkan Peraturan Menteri Kesehatan Republik Indonesia Nomor 66 Tahun 2016 tentang Keselamatan dan Kesehatan Kerja Rumah Sakit bahwa keselamatan kerja adalah upaya yang dilakukan untuk mengurangi terjadinya kecelakaan, kerusakan dan segala bentuk kerugian baik terhadap manusia, maupun yang berhubungan dengan peralatan, obyek kerja, tempat bekerja, dan lingkungan kerja secara langsung dan tidak langsung.

Jadi keselamatan dan kesehatan kerja (K3RS) adalah suatu tindakan untuk melindungi tenaga kesehatan ataupun pekerja lainnya dari resiko,kecelakaan dan bahaya dalam menjalankan tugas di rumah sakit. Rumah sakit adalah salah satu pelayanan kesehatan yang memberikan pelayanan kesehatan berupa jasa dimana di dalamnya terdapat banyak kegiatan seperti pelayanan rawat jalan, pelayanan rawat inap, dan pelayanan rawat darurat yang mencakup pelayanan medik.

\section{Tujuan}

Tujuan dari keselamatan dan kesehatan kerja adalah mencegah, megurangi, bahkan meminimalkan resiko penyakit dan kecelakaan akibat kerja (KAK) serta meningkatkan derajat kesehatan para pekerja sehingga produktivitas kerja meningkat. Selain itu bertujuan untuk peningkatan kesehatan dan perlindungan khusus kepada pekerja.

\section{Faktor -faktor yang menyebab terjadinya kecelakaan kerja dan penyakit akibat kerja}

Menurut WHO yang dikutip oleh Swarjana (2017), faktor-faktor yang menyebab terjadinya kecelakaan kerja dan penyakit akibat kerja adalah:

a) Faktor manusia. Adapun faktor yang menyebabkan manusia dapat menimbulkan kecelakaan kerja atau penyakit akibat kerja diantaranya adalah umur, pengalaman kerja, penggunaan obat, dan motivasi. 
b) Faktor lingkungan. Adapun penyebab kecelakaan kerja lainnya adalah faktor lingkungan pekerjaan. Seperti tingkat pencahyaan, tingkat kebisingan, temperature atupun suhu lingkungan, kesalahan konstruksi mesin, sikap badan yang tidak benar dalam melakukan pekerjaan, dan yang lain sebagainya.

c) Faktor organisasi. Kecelakaan kerja merupakan sebuah kejadian yang tidak diinginkan oleh siapa pun. Setiap pekerja pasti menginginkan untuk bekerja dengan nyaman, aman tanpa ada rasa cemas akan terjadinya kecelakaan di lingkungan kerja. Oleh karena itu, lingkungan sosial atau organisasi memiliki efek paling besar terhadap kinerja seseorang.

\section{Pelaksanaan keselamatan dan kesehatan kerja di rumah sakit (K3RS)}

Adapun pelaksanaan keselamatan dan kesehatan kerja di rumah sakit, meliputi :

a. Melakukan manajemen risiko. Manajemen risiko adalah sebuah proses yang bertahap dan berkesinambungan untuk mencegah terjadinya kecelakaan dan penyakit akibat kerja secara komperhensif di lingkungan rumah sakit. Tujuannya adalah untuk meminimalkan risiko keselamatan dan kesehatan di rumah sakit dan tidak menimbulkan efek buruk terhadap keselamatan dan kesehatan SDM rumah sakit, pasien, pendamping pasien, pengunjung, maupun lingkungan rumah sakit.

b. Melakukan pelayanan kesehatan kerja. Pelayanan kesehatan kerja adalah suatu bentuk upaya jaminan kesehatan yang diberikan kepada para pekerja seperti tenaga kesehatan dan profesi lainnya di rumah sakit untuk meningkatkan dan memelihara kesehatan baik secara fisik, mental, dan sosial.

\section{Kesehatan dan Keselamatan Kerja dalam Asuhan Keperawatan}

Kesehatan dan Keselamatan Kerja (K3) merupakan suatu upaya untuk mengendalikan, meminimalisasi dan meniadakannya bahaya di rumah sakit dapat dilakukan melalui sistem K3RS. Dan K3 juga seharusnya wajib dilakukan dalam memberikan asuhan keperawatan agar meminimalisir kejadian yang tidak diinginkan terjadi, baik itu kecelakan dalam bekerja ataupun tindakan yang bisa mendatangkan penyakit. Perawat menjadi salah satu profesi yang harus menerapkan K3 ini sendiri dalam melakukan tindakan keperawatan kepada pasien ketika berada di rumah sakit. 


\section{Langkah dan Strategi Pelaksanaan Kesehatan dan Keselamatan Kerja di Rumah Sakit (K3RS)}

Adapun langkah dan straterginya adalah sebagai berikut:

a) Advokasi ke pimpinan RS, sosialisasi dan pembudayaan K3RS.

b) Menyusun kebijakan K3RS yang ditetapkan oleh Pimpinan RS.

c) Membentuk Organisasi K3RS.

d) Perencanaan K3 sesuai standar K3RS yang ditetapkan oleh Depkes.

e) Menyusun pedoman dan SOP K3RS diantaranya sebagai berikut:

- pedoman praktis ergonomi di rumah sakit;

- pedoman pelaksanaan pelayanan kesehatan kerja;

- pedoman pelaksanaan pelayanan keselamatan kerja;

- pedoman pelaksanaan penanggulangan kebakaran;

- pedoman pelaksanaan tanggap darurat di rumah sakit;

- pedoman pengelolaan penyehatan lingkungan rumah sakit;

- pedoman pengelolaan faktor risiko di rumah sakit;

- pedoman pengelolaan limbah rumah sakit;

- pedoman kontrol terhadap penyakit infeksi;

- pedoman control terhadap bahan berbahaya dan beracun (B3);

- penyusunan SOP kerja dan peralatan masing-masing unit kerja rumah sakit

f) Melaksanakan 12 program K3RS yang telah disebutkan sebelumnya

g) Melakukan evaluasi pelaksanaan K3RS.

h) Melakukan internal audit program K3RS dengan menggunakan instrument self assessment akreditasi rumah sakit yang berlaku.

i) Mengikuti Akreditasi rumah sakit.

\section{PENUTUP}

Pelaksanaan keselamatan dan kesehatan kerja sangat penting di rumah sakit. Terutama bagi perawat. Perawat merupakan orang yang sering kontak langsung dengan klien. Kesehatan dan Keselamatan Kerja (K3) adalah suatu sistem yang membuat asuhan keperawatan terhadap pasien lebih aman, baik itu dalam pelaporan, analisis insiden dan kemampuan belajar dari insiden dan tindak lanjutnya. Tujuan dari keselamatan dan kesehatan kerja adalah mencegah, 
megurangi, bahkan meminimalkan resiko penyakit dan kecelakaan akibat kerja (KAK) serta meningkatkan derajat kesehatan para pekerja sehingga produktivitas kerja meningkat. Selain itu bertujuan untuk peningkatan kesehatan dan perlindungan khusus kepada pekerja. Oleh sebab itu maka perlu ditingkatkan lagi upaya keselamatan dan kesehatan di rumah sakit agar tidak terjadi kejadian yang tidak di inginkan.

\section{Daftar Pustaka}

Ernawati , N., \& Nurlelawati, E. (2017). FAKTOR-FAKTOR YANG BERHUBUNGAN DENGAN PELAKSANAAN PENERAPAN K3 PADA TENAGA KESEHATAN DI RSIA PERMATA SARANA HUSADA PERIODE FEBRUARI 2015. Jurnal Akademi Keperawatan Husada Karya Jaya, Vol 3, No 1, 12-18.

Hasibuan, R. (2017). PENGARUH KESELAMATAN KERJA PELATIHAN DAN KERJA TIM TERHADAP KINERJA TENAGA MEDIS DI RUMAH SAKIT BUDI KEMULIAAN BATAM. Jurnal Dimensi 6 (2), 323-328.

Hidayah, Wulan Fatwa . (2019) . ANALISIS FAKTOR RISIKO DAN HAZARD DALAM IMPLEMENTASI KEPERAWATAN. Bachelor Thesis, UNIVERSITAMUHAMMADIYAH PURWOKERTO.

Ivana, A., \& dkk. (2014). Analisa Komitmen Manajemen Rumah Sakit (RS) Terhadap Keselamatan Dan Kesehatan Kerja (K3) Pada RS Prima Medika Pemalang. Jurnal Kesehatan Masyarakat (e-Journal) Vol 2, No 1, 35-41.

Nazirah, R., \& Yuswardi. (2017). PERILAKU PERAWAT DALAM PENERAPAN MANAJEMEN KESEHATAN DAN KESELAMATAN KERJA (K3) DI ACEH. Idea Nursing Journal Vol. VIII No. 3.

Rejeki, S. (2016). KESEHATAN DAN KESELAMATAN KERJA. Jakarta: KEMENTERIAN KESEHATAN REPUBLIK INDONESIA.

Rifai, M. (2017). HUBUNGAN PENGETAHUAN DAN PARTISSIPASI KESELAMATAN DAN KESEHATAN KERJA (K3) PADA PERAWAT DENGAN KEJADIAN 
KECELAKAAN KERJA DI RUMAH SAKIT X YOGYAKARTA. Jurnal Publikasi Kesehatan Masyarakat Indonesia Vol 4, No 3, 88-92.

Sembiring, Sisilia Feagitha. 2018. “Penerapan Keselamatan dan Kesehatan Kerja di Rumah Sakit Umum Daerah Kabanjahe Kabupaten Karo Sumatera Utara “. Skripsi. FAKULTAS KESEHATANMASYARAKAT. ILMU KESEHATAN MASYARAKAT. UNIVERSITAS SUMATERA UTARA. Medan

Simamora, R. H. (2011). ROLE CONFLICT OF NURSE RELATIONSHIP WITH PERFORMANCE IN THE EMERGENCY UNIT OF HOSPITALS RSD DR. SOEBANDI JEMBER. The Malaysian Journal of Nursing, 3(2), 23-32.

Sujoso, A. D. (2012). DASAR-DASAR KESELAMATAN DAN KESEHATAN KERJA. Jember: UPT Penerbitan UNEJ.

Tukatman, \& dkk. (2015). ANALISIS KESELAMATAN DAN KESEHATAN KERJA PERAWAT DALAM PENANGANAN PASIEN DI RUMAH SAKIT BENYAMIN GULUH KABUPATEN KOLAKA. Jurnal Ners Vol. 10 No. 2, 343-347. 